\title{
Manifestation of metastatic lung adenocarcinoma as Gerstmann syndrome
}

\author{
Albert Jang (1), ${ }^{1}$ Tameka A Smith, ${ }^{1}$ Steven Trainor, ${ }^{2}$ Peter C Caldwell ${ }^{3}$
}

${ }^{1}$ Internal Medicine, Tulane University School of Medicine, New Orleans, Louisiana, USA ${ }^{2}$ Neurology, Southeast Louisiana Veterans Health Care System, New Orleans, Louisiana, USA ${ }^{3}$ Internal Medicine, Southeast Louisiana Veterans Health Care System, New Orleans, Louisiana, USA

\section{Correspondence to \\ Dr Albert Jang; \\ ajang@tulane.edu}

Accepted 23 September 2020

Check for updates

(C) BMJ Publishing Group Limited 2020. No commercial re-use. See rights and permissions. Published by BMJ.

To cite: Jang A, Smith $T A$, Trainor S, et al. BMJ Case Rep 2020;13:e238098. doi:10.1136/bcr-2020238098

\section{DESCRIPTION}

A man in his late 60 s presented after 1 day of altered mental status. He reported confusion, trouble communicating his thoughts and difficulty speaking. He was afebrile and haemodynamically stable. His neurological exam was notable for neglecting sensation to his right side; otherwise, his cranial nerves II-XII were intact, motor strength was $5 / 5$ bilaterally and reflexes were equal bilaterally. CT of the head without contrast showed no acute intracranial abnormalities. CT angiography of the head and neck revealed supraclavicular lymphadenopathy and a $6 \mathrm{~mm}$ pulmonary nodule in the superior right lower lobe. MRI of the brain revealed scattered areas of ischaemia in the left parietal and posterior temporal lobe in the distribution of the left middle cerebral artery (figure 1), as well as several emboli throughout the brain (figure 2). A transthoracic echocardiogram with bubble study showed a patent foramen ovale. Doppler ultrasound of the legs showed thrombi in the right popliteal, left popliteal, left common femoral and left superficial femoral veins.

The patient was discovered to have other cognitive deficits during the hospitalisation. He was only able to read short sentences with significant effort, and struggled to read long sentences. He could not write his own name. He had poor short-term recall of a list of four digits and was unable to repeat a list of three digits in reverse. He was unable to perform simple addition and subtraction. He identified most of his fingers bilaterally as his left thumb.

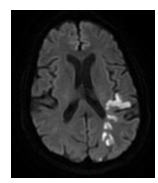

Figure 1 Cortical, subcortical and deep white matter subacute ischaemia in the left parietal and posterior temporal lobe, in the distribution of the left middle cerebral artery and possibly left posterior cerebral artery, seen on diffusion-weighted MRI.

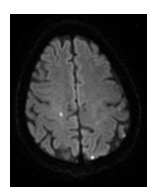

Figure 2 Scattered areas of subacute ischaemia distributed throughout the brain, suggesting embolic phenomena, seen on diffusion-weighted MRI.

\section{Learning points}

- Gerstmann syndrome, a tetrad consisting of agraphia, acalculia, right-left disorientation and finger agnosia, involves damage to the inferior parietal lobe near the parietal and temporal lobe junction, and it can be revealed on MRI of the brain.

- Paradoxical embolism may cause Gerstmann syndrome, and a transthoracic echocardiogram with bubble study is recommended to rule out patent foramen ovale.

A clinical diagnosis of Gerstmann syndrome was made. Further imaging was performed. CT of the chest, abdomen and pelvis revealed a right lower lobe pulmonary embolism, multiple bilateral pulmonary nodules, mediastinal lymphadenopathy and a T8 mass with a pathological fracture. A lymph node biopsy was completed, and he was diagnosed with stage IV adenocarcinoma of the lung.

This patient experienced the classic tetrad of Gerstmann syndrome, which consists of agraphia, acalculia, right-left disorientation and finger agnosia. ${ }^{1}$ MRI images supported this diagnosis with lesions at the temporal and parietal lobe junction. Extremely few case reports document Gerstmann syndrome associated with a non-central nervous system malignancy, as presented here. ${ }^{23}$ In addition, a paradoxical embolism leading to the diagnosis of Gerstmann syndrome is a rare event, with only one other case found in the literature. ${ }^{4}$ Malignancies, especially adenocarcinomas which have increased tendency to secrete procoagulant and fibrinolytic substances and inflammatory cytokines, promote a prothrombotic state. ${ }^{5}$

This is a rare documented report of a patient where a clinical diagnosis of Gerstmann syndrome led to a full workup revealing several deep venous thrombi, a patent foramen ovale and stage IV adenocarcinoma of the lung in addition to a preexisting prostate adenocarcinoma. The patient was stable during hospitalisation and was discharged home on apixaban.

This case highlights the importance of recognising the presentation of Gerstmann syndrome, as it can assist with localising parietal lobe pathology. Consider ruling out a paradoxical embolism or deep venous thrombosis when considering the aetiology of Gerstmann syndrome.

Acknowledgements We thank Amy Yu, DO in the Department of Radiology for providing the images for this article. 
Contributors AJ conceptualised and wrote the article. TS, ST and PC offered guidance and suggestions, and edited the article. All authors participated in patient care and approved the final version of the article.

Funding The authors have not declared a specific grant for this research from any funding agency in the public, commercial or not-for-profit sectors.

Competing interests None declared.

Patient consent for publication Not required.

Provenance and peer review Not commissioned; externally peer-reviewed.

\section{ORCID iD}

Albert Jang http://orcid.org/0000-0002-0461-6174

\section{REFERENCES}

1 Gerstmann J. Syndrome of finger agnosia, disorientation for right and left, agraphia and acalculia. Arch NeurPsych 1940;44:398-408.

2 Pérez Rodríguez E, Domínguez Moronta F, del Pino Montes J, et al. [Gerstmann's syndrome as the first manifestation of gastric adenocarcinoma]. Rev Clin Esp 1985;177:359.

3 Miyake T, Konda S. [Gerstmann's syndrome due to lung neoplasm metastasis]. Naika 1963;12:306.

4 Bhattacharyya S, Cai X, Klein JP. Dyscalculia, dysgraphia, and left-right confusion from a left posterior peri-insular infarct. Behav Neurol 2014;2014:1-4.

5 Caine GJ, Stonelake PS, Lip GYH, et al. The hypercoagulable state of malignancy: pathogenesis and current debate. Neoplasia 2002;4:465-73.

Copyright 2020 BMJ Publishing Group. All rights reserved. For permission to reuse any of this content visit

https://www.bmj.com/company/products-services/rights-and-licensing/permissions/

BMJ Case Report Fellows may re-use this article for personal use and teaching without any further permission.

Become a Fellow of BMJ Case Reports today and you can:

- Submit as many cases as you like

- Enjoy fast sympathetic peer review and rapid publication of accepted articles

- Access all the published articles

Re-use any of the published material for personal use and teaching without further permission

Customer Service

If you have any further queries about your subscription, please contact our customer services team on +44 (0) 2071111105 or via email at support@bmj.com.

Visit casereports.bmj.com for more articles like this and to become a Fellow 